\title{
Performance Evaluation of Three Different Grasses for Use as Willows in Greywater Treatment in Semi-arid Ghana
}

\author{
1"ADONADAGA, M-G, ${ }^{1}$ TAKRAMAH, BKS; ${ }^{1}$ AMPADU, B; ${ }^{2}$ SACKEY, I \\ ${ }^{{ }^{*}}$ Department of Environmental Science, Faculty of Earth and Environment Sciences, University for Development Studies, P.O. Box 24, \\ Navrongo, Ghana. \\ ${ }^{2}$ Department of Applied Biology, Faculty of Applied Sciences, University for Development Studies, P.O. Box 24, Navrongo, Ghana. \\ *Corresponding Author Email: amelvin@uds.edu.gh
}

\begin{abstract}
The focus of this experimental study was to identify appropriate grass for use as willows for greywater treatment in constructed wetlands. Cymbopogon flexuosus (lemon grass), Pennisetum purpureum (elephant grass) and Andropogon gerardi (giant bluestem) were planted separately and watered with greywater for a period of fifteen weeks. Growth measurements were recorded weekly and the quality of the effluents from each of these grasses assessed using standard methods to determine their treatment efficiency. Elephant grass recorded the highest plant height of $88.9 \mathrm{~mm}$ and the highest number of new leaves of 49 , while lemon grass recorded the largest surface area of $5502 \mathrm{~mm}^{2}$. With regards to treatment performance, lemon grass recorded the highest efficiency with reductions of $80 \%$ in TDS, $81 \%$ in $\mathrm{NO}_{3}-\mathrm{N}, 30 \%$ in $\mathrm{PO}_{4}-\mathrm{P}$ and $82 \%$ in BOD. Except for BOD that was missed by elephant grass and giant bluestem, all the other effluent parameters met the WHO guidelines. A scaling up of the experiment for continuous greywater feed and over a longer period is recommended in order to ascertain the performance over time.
\end{abstract}

DOI: https://dx.doi.org/10.4314/jasem.v24i1.26

Copyright: Copyright $@ 2020$ Adonadaga et al. This is an open access article distributed under the Creative Commons Attribution License (CCL), which permits unrestricted use, distribution, and reproduction in any medium, provided the original work is properly cited.

Dates: Received: 30 November 2019; Revised: 20 December 2019; Accepted: 23 December 2019

Keywords: Greywater treatment, willows efficiency, growth measurements.

Water is an important resource and component of the environment with significant benefits to living organisms and nature as a whole. It is critical to sustainability and socio-economic growth, healthy environment and human survival. In addition to being central in lowering the global disease burden and enhancing population health, social wellbeing and productivity, water also plays a key role in generating, maintaining and delivering many services to individuals (UNDESA, 2015). Directly linked to these uses is the production of wastewater, defined as water that has been used for its intended purpose and contains physical, chemical and biological pollutants. Domestic wastewater normally includes greywater (sullage) that is generated by wastewater produced from washrooms, bathrooms, laundries, kitchens as well as black water consisting of urine, excretes and toilet flush water. The mixture if channelled into a sewer scheme or into a septic tank is known as sewage (Obuobie et al., 2006). Domestic wastewater contains significant quantities of pollutants including complex organic components, nitrogen compounds, phosphorus-rich substances and pathogens (bacteria, viruses and protozoa) which can cause significant health risks if not properly managed (Ambulkar and Nathanson, 2010; Mesdaghinia et al., 2004). According to a United Nations evaluation cited by Berman (2009), about four thousand kids die every day as consequences of water-related illnesses, and four out of ten individuals on the globe have no clean water to drink, especially those in Africa and Asia. Wastewater, if properly treated, can be a source of reliable water and nutrients supply for agricultural practices (World Health Organization, 2019). According to Agbozo et al. (2003), approximately 280 million cubic meters of wastewater is produced from urban Ghana. This could be treated for irrigation or other agricultural purposes as a means of improving the health and livelihoods of the people. In addition, this has the potential of significantly reducing the instances of eutrophication associated with the huge volumes of wastewater discharged into lakes, rivers and oceans the world over (World Health Organization, 2019). Goal six of the Sustainable Development Goals (SDG 6) calls for water and sanitation to be accessible and sustainable for all. This objective may not be achieved if many people still lack access to safe water supplies and sanitation. Water scarcity remains a major obstacle to social and economic growth, especially among the poor and vulnerable. Hence, in order to balance the competitive and growing water demand in multiple industries, improved water management and increased water effectiveness are essential (Sustainable Development Goals Report, 2018).Conventional methods of wastewater treatment such as trickling filter and activated sludge are

*Corresponding Author Email: amelvin@uds.edu.gh 
generally not suitable for developing countries due to significant costs associated with high energy demands for pumping, aeration and maintenance work associated with them. (UFZ, 2011; ORGANICA, 2019). As alluded to by Asante (2014), nonconventional methods employing some form of phytoremediation such as waste stabilization ponds and constructed wetlands which are cheap, efficient and relatively easy to build should be explored for wastewater treatment. Constructed wetlands are aquatic systems that use mainly aquatic plants for the treatment of wastewater (Crites and Tchobanoglous, 1998). These systems are basically designed to take advantage of processes such as sedimentation, filtration, chemical precipitation, microbial interaction, plant assimilation and adsorption to soil particles (Horváth, 2012). Thus, they reach a high level of treatment with a relatively small amount of maintenance required. Willows, also known as reed beds, have been used in constructed wetlands for treating domestic wastewater of low strength (Börjesson and Berndes, 2006). These willows comprise of species such as Phragmites australis, Glyceria sp. (Mannagrasses), Eleocharis spp. (Spikerushes), Typha spp. (Cattails), Scirpus spp. (Bulrushes), Iris spp. (Blue/Yellow Flags) and Zizania aquatica (Wild Rice) (US-EPA, 2000).

In Ghana, about $78 \%$ of homes are not connected to any sewage system, and less than $8 \%$ of generated wastewater receives some form of treatment (UNDP, 2011; Gyampo, 2012). In the Upper East region for instance, an assessment by UNICEF (2016) indicated that no treatment plant existed due mainly to high cost of cnventional treatment plants. The objective of this research work was to evaluate some physicochemical parameters of greywater after separately using Cymbopogon flexuosus (lemon grass), Pennisetum purpureum (elephant grass) and Andropogon gerardi (giant bluestem) as willows in constructed wetlands in Ghana.

\section{MATERIALS AND METHODS}

Study Area: The research was performed in Navrongo in the Municipality of Kassena Nankana, Upper East region of Ghana. The Kassena Nankana Municipality lies within the Guinea Savannah woodlands. It is located approximately between latitude $11^{\circ} 10^{\prime}$ and $10^{\circ} 3^{\prime}$ North and longitude $10^{\circ} 1^{\prime}$ West, with its administrative capital being Navrongo (Ghana Districts, 2009). It has boundaries with the western district of Kassena-Nankana in the north, the city of Bolgatanga in the east, Builsa and Kassena-nankana in the west, and West Mamprusi in the south (Kassena Nankana East Assembly, 2015). The municipal population is 109,944 , with $53,676(48.8 \%)$ men and
56,268 (51.2 \%) women, based on the 2010 population and housing census (Kassena Nankana East Assembly, 2015).

Identification and Planting of willows: The following grasses were selected for the experiment: Pennisetum purpureum (elephant grass), Andropogon gerardi (giant bluestem), and Cymbopogon flexuosus (lemon grass). These are drought tolerant perennial grasses widely naturalized in tropical and sub-tropical regions, well adapted to grow on wide range of soil types, and capable of growing in a rainfall range of $200-4000 \mathrm{~mm}$ (Clayton et al., 2013). They are used to control soil erosion on arid lands and also serve as a mulching material. In Ghana, these grasses are usually associated with ecological zones prone to recurrent annual bushfires, particularly in transitions between forest belts and the savannah ecological zones (Danquah et al., 2018). These properties informed the choice of these grasses for the experiment. They were collected from the project site of the Department of Agriculture (DoA) in the municipality with the support of an agricultural scientist, and planted that same day to prevent wilting. The soil used for the experiment was clayey-loamy, and was collected from the premises of the DoA, Navrongo and transported to the University for Development Studies (UDS) Navrongo campus where the experimental set-up was done. Slashed plastic gallons were used as a planter box to support planting materials, with six stumps of each grass planted in the container (Fig 1). The dimensions of the containers are given in Table 1.

\begin{tabular}{llll}
\multicolumn{4}{c}{ Table 1: Dimensions of slashed gallons } \\
\hline Measurement & $\begin{array}{l}\text { Medium A } \\
\text { (Lemon }\end{array}$ & $\begin{array}{l}\text { Medium B } \\
\text { (Elephant }\end{array}$ & $\begin{array}{l}\text { Medium C } \\
\text { (Big }\end{array}$ \\
& Grass) & Grass) & Bluestem) \\
\hline Length (mm) & 41.5 & 42.5 & 44 \\
Width (mm) & 22.8 & 22 & 24 \\
Depth (mm) & 16 & 16 & 17 \\
\hline
\end{tabular}

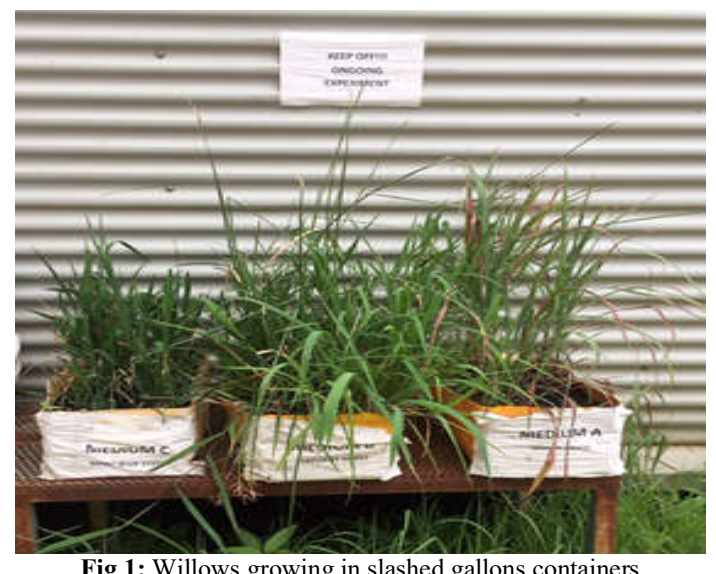

Fig 1: Willows growing in slashed gallons containers 
The grasses were watered daily with $1.5 \mathrm{~L}$ of greywater collected from a hall of residence on the university campus. Also, other sources of water such as rain had its own infiltration each time there was a downpour as the experiment was in the open to ensure closeness to natural conditions.

Growth Measurements: Growth measurements comprised of the recording of plant height, number of new leaves and the surface area of the leaves on a weekly basis for the fifteen weeks of the experiment. For plant height, a $30 \mathrm{~cm}$ graduated rule was used. This was done by affixing the rule to the edge of the container and the reading corresponding to the tip of the plant taken. This action was done for the three plants in a zigzag manner to ensure an equal and fair distribution, and the average reading recorded. The new leaves were observed by eye inspection and the number of new leaves observed for each stump were counted and recorded. The surface area of the leaves was determined by tracing the most developed and vertically grown leaf of each of the respective willow mediums on a graph sheet. After this, the number of square boxes covered by the sketch of the leaf on the graph sheet was counted and multiplied by $2 \mathrm{~mm}^{2}$ (size of small grid box), and the result multiplied by two to cater for the upper surface and lower surface of the leaf. This arithmetic calculation then gives an estimate of the surface area for each leaf.

Sample Collection and Handling: Sample analyses were carried out at the laboratory of the Council for Scientific and Industrial Research, Water Research Institute (CSIR-WRI), Tamale. The samples were the raw greywater (influent) and the effluents from the three containers. The influent was collected in a 1.5 litre plastic bottle with labelling INF/01 and transported in cold ice to enable for sample noncontamination and effective laboratory analysis (adhering to water and wastewater sampling and preservation protocols). Starting from the eleventh week, effluent samples were prepared by mixing soil samples from each container with distilled water. The mixture was vigorously shaken and allowed to stand for some time for the settling of the solids. Next, the liquid was decanted and taken for analysis. This process was repeated for the next week. Effluent sample containers were labelled LMN, ELP, and GBS representing lemongrass, elephant grass and giant blue stem respectively.

Analytical methods: The physicochemical parameters analysed were Total Dissolved Solids (TDS), $\mathrm{pH}$, Biochemical Oxygen Demand (BOD), Nitrogen (N), and Phosphorus (P). $\mathrm{pH}$ and TDS measurements were done using their respective electronic probes, and the results displayed on an electronic screen. BOD was determined based on the $\mathrm{BOD}_{5}$ method while $\mathrm{P}$ and $\mathrm{N}$ concentrations were detrmined using standard methods (APHA, 1998).

\section{RESULTS AND DISCUSSION}

Plant height: Figure 2 shows that the overall plant height for lemon grass increased from $52.16 \mathrm{~mm}$ in week one to $83.6 \mathrm{~mm}$ in week eight, and remained so for the rest of the weeks, an indication that the lemon grass has either attained its maximum height or other factors were preventing its growth. For elephant grass, the height increased from $36.5 \mathrm{~mm}$ in week one to $88.9 \mathrm{~mm}$ in week nine, representing a percentage increase of almost 59\%. The height of giant blue stem increased from $23.4 \mathrm{~mm}$ in week three to $67.06 \mathrm{~mm}$ in week fifteen, which represents a percentage increase of $65 \%$. Hence, unlike lemon and elephant grass that stopped increasing in height at week eight and nine respectively, giant blue stem continued to grow throughout the period of the experiment. A possible reason for this could be that lemon grass and elephant grass had reached their peak heights at week nine, but giant blue stem, which showed to be a slow grower, had not peaked yet. Number of new leaves: Overall, the number of new leaves for lemon grass increased from 14 in week one to 20 in week fifteen, which represents a percentage increase of $30 \%$, with the maximum number of new leaves as 48 in week eight for lemon grass (Fig 3). Overall, the number of new leaves for elephant grass increased from 17 in week one to 49 in week eight, representing an increase of $65 \%$. After week eight, there was a decrease in the rate of new leaves production, dropping in percentage from the $65 \%$ to $26 \%$. This trend was similarly observed for lemon grass (Fig 3). Depletion in soil nutrients or accumulation of certain metabolites resulting in a change in the chemical composition of the soil could be possible reasons for the reduction in production of new leaves after week eight.

Surface area: At the end of the fifteen weeks, the plant with the maximum surface area was lemon grass with $5502 \mathrm{~mm}^{2}$ in week nine and $1100 \mathrm{~mm}^{2}$ as minimum surface area for giant blue stem in week one (Fig 4).

Laboratory Analysis: The physicochemical parameters measured so as to assess the efficiency of the willows in treating the wastewater are $\mathrm{pH}$, Total Dissolved Solids (TDS), Nitrate, Phosphate, and Biochemical Oxygen Demand (BOD). The results obtained are presented in the table 2 


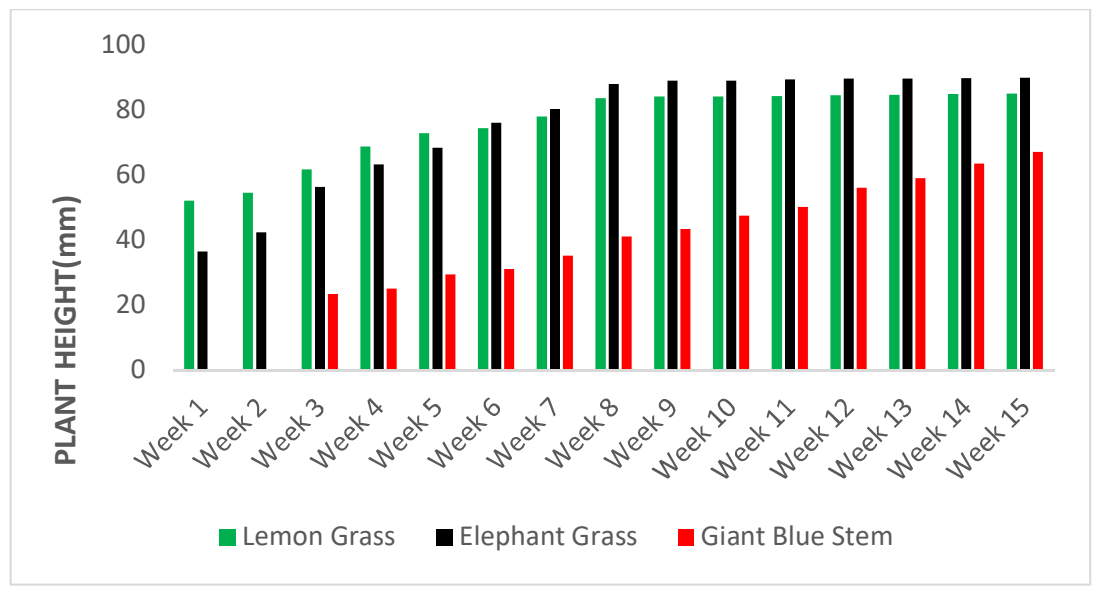

Fig 2: Height of various willows over fifteen weeks growth period

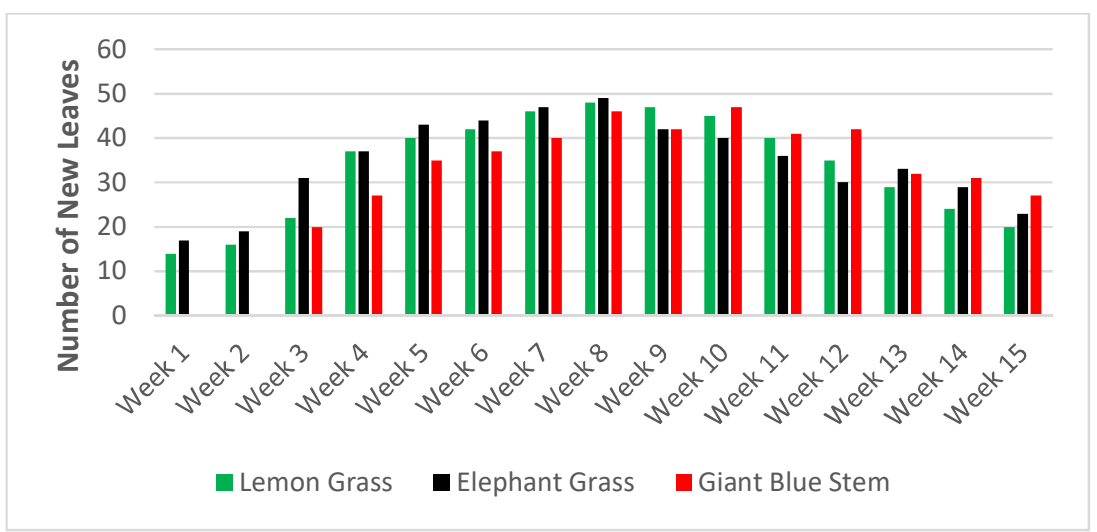

Fig. 3: Number of new leaves of various willows over fifteen weeks growth period

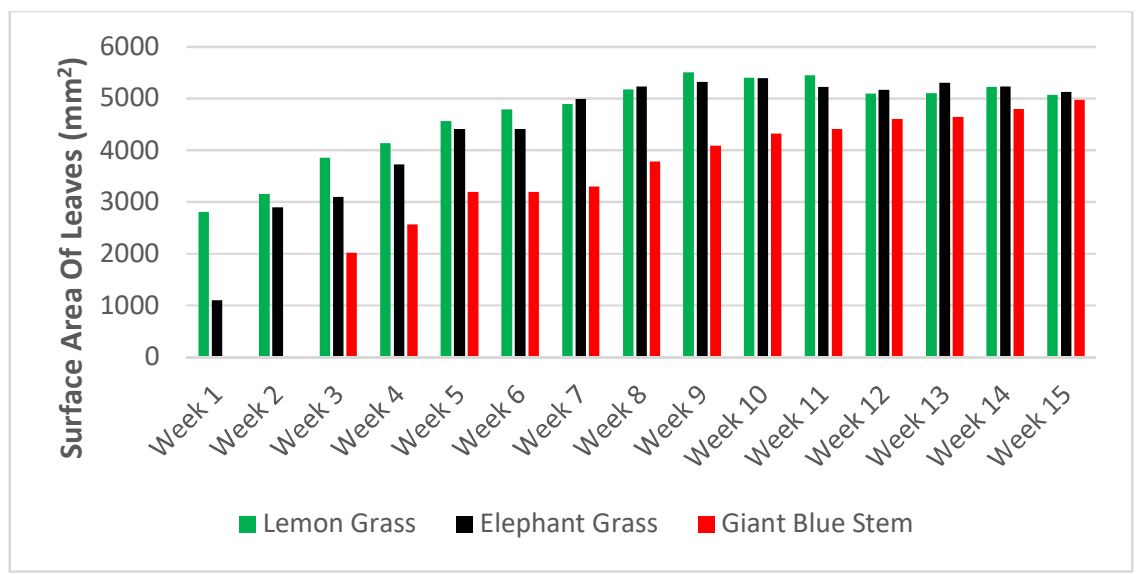

Fig. 4: Surface area of leaves of various willows over fifteen weeks growth period Table 2: Levels of physicochemical parameters of influent and effluents

\begin{tabular}{llllll}
\hline \multicolumn{5}{c}{ SAMPLE ID } \\
\hline Parameters & Influent & Lemon Grass & Elephant Grass & Giant Blue Stem & WHO Guideline \\
\hline $\mathrm{pH}-\mathrm{pH}$ units & 7.79 & 7.6 & 7.8 & 7.7 & $6.5-8.5$ \\
$\mathrm{TDS}(\mathrm{mg} / \mathrm{l})$ & 757 & 225 & 142 & 239 & 1000 \\
$\mathrm{NO}_{3}-\mathrm{N}(\mathrm{mg} / \mathrm{l})$ & 5.835 & 1.9 & 2.9 & 2.4 & 50 \\
$\mathrm{PO}_{4}-\mathrm{P}(\mathrm{mg} / \mathrm{l})$ & 1.012 & 0.7 & 0.5 & 1.0 & 2 \\
$\mathrm{BOD}(\mathrm{mg} / \mathrm{l})$ & 132 & 24 & 62 & 180 & 50 \\
\hline
\end{tabular}


Total Dissoved Solids (TDS): TDS is a measurement of inorganic salts, organic matter and other dissolved materials in water. The toxicity of TDS is influenced by increases in salinity, changes in the ionic composition of the water, and toxicity of individual ions (CISRO, 2006). The measured concentrations of influents and effluents were within the WHO guidelines of $1000 \mathrm{mg} / \mathrm{l}$ and hence satisfactory. The various concentrations of the effluents were generally below $300 \mathrm{mg} / 1$ and this could suggest low concentrations of dissolved inorganic and organic molecules and ions present in the effluents. Kagya (2011) in his study on effluent quality of two wastewater treatment systems, also reported a low value of $329.0 \mathrm{mg} / \mathrm{l}$ in the final effluent discharged into water bodies. The removal of TDS in this study is in the ranking order of Elephant grass $>$ Lemon grass $>$ Giant blue stem.

Nitrate $\left(\mathrm{NO}_{3}-\mathrm{N}\right)$ : Nitrate is the end product of the aerobic stabilization of organic nitrogen and may enter the environment via run offs from agricultural lands or in treated effluents from wastewater plants. The influent concentration of nitrate in the raw wastewater was $5.835 \mathrm{mg} / \mathrm{l}$, which was well within the discharge standards of WHO at $50.0 \mathrm{mg} / 1$. According to Vymazal and Kröpfelová (2008), bacterial denitrification and plant uptake have the greatest nitrogen removal potentials. These bacteria attach themselves to the walls of their mediums (Metcalf and Eddy, 1991). The slashed gallons (willow containments) may have provided the favourable habitat for the nitrifying bacteria hence the significant reduction of nitrate in those treatment units. The rate of nitrification also depends on a number of factors including temperature and the amount of oxygen (Vymazal and Kröpfelová, 2008). These two factors were at appreciable levels since the experimental setup was left in the open to achieve close to nature conditions and thereby provides reasons why there was significant reduction of nitrates in these units. Nitrogen is the most critical and imperative nutrient assimilated by plants for proper growth and development, either as ammonia or nitrates and used in the production of biological macromolecules such as amino acids and nucleotide bases (Shah et al., 2016). The selected plants are not so different from other plants taking up nitrogen as either ammonia or nitrates. The observed decreases in the concentration of nitrates in the effluent samples may be attributed to assimilation by the plants or could also be due to the process of denitrification in which nitrates are reduced to molecular nitrogen gas $\left(\mathrm{N}_{2}\right)$ (Mustapha, 2013; Akinbile and Yusoff, 2012). However, effluent treatment with the selected willows showed significant nitrate removal efficiency of $81 \%$,
$65 \%$ and $56 \%$ for lemon grass, giant blue stem and elephant grass respectively. These results agree with the conclusions by Börjesson and Berndes (2006) that willow root system take up $75-95 \%$ of nitrogen and phosphorus in the wastewater.

Phosphate $\left(\mathrm{PO}_{4}-\mathrm{P}\right)$ : The influent concentration of phosphate recorded was $1.012 \mathrm{mg} / \mathrm{l}$, which is well within the WHO guideline value of $2.0 \mathrm{mg} / 1$. All the grasses yielded some levels of reductions. Significant reduction of $50.6 \%$ of phosphate was observed in elephant grass ( 1.012 to $0.5 \mathrm{mg} / \mathrm{l}), 31 \%$ in lemon grass (from 1.012 to $0.7 \mathrm{mg} / \mathrm{l}$ ) and finally $12 \%$ in giant blue stem (from 1.012 to $1.0 \mathrm{mg} / \mathrm{l}$ ). These reductions could be due to the presence of polyphosphate accumulating organisms present on the filter media, uptake by roots or sedimentation mechanisms (Guidi et al., 2015). These organisms can accumulate large quantities of up to $20 \%$ their mass of phosphorus in their cells. Phosphorus is the only plant nutrient that can trigger plant growth when introduced into an aquatic environment or its similitude (Nkegbe et al., 2005). Nitrogen and phosphorus interact to produce large standing crops of algae (Dorgham, 2014). When added singly, phosphorus caused increase in standing crops of algae, whereas nitrogen alone did not elicit a response (Mason, 1996). This showed that phosphorus controls the growth of phytoplankton hence its limitation reduces the problem of eutrophication. A concentration of $0.01 \mathrm{mg} / 1$ phosphorus can result in eutrophication (Nkegbe et al., 2005). In the present study, the level of phosphate in one of the effluents was $1.073 \mathrm{mg} / \mathrm{l}$. This high phosphate concentration in the final effluent might have promoted the growth of algae in its willow containment. The removal efficiency in decreasing order as shown in this work is as follows: elephant grass $>$ lemon grass $>$ giant blue stem.

Biochemical Oxygen Demand (BOD): BOD is the most important variable in water pollution control since it indicates the actual level of biodegradable pollutants in the water (Bitton, 2005). The influent sample recorded a BOD of $132 \mathrm{mg} / \mathrm{l}$. Also, the effluents from elephant grass and giant blue stem recorded BOD levels that exceeded the WHO standard guidelines of $50 \mathrm{mg} / \mathrm{l}$ for wastewater, with only lemon grass meeting the standard (Table 2). However, all the grassess achieved BOD reductions of between $36 \%$ to $82 \%$. The high BOD concentrations in the effluents can cause depletion of natural oxygen resources which may lead to the development of septic conditions in receiving waters (Hodgson, 2000). Kagya (2011) argued that high levels of BOD is a result of the presence of considerable amounts of organic materials 
available for biodegradation.

Conclusion: The results indicated that only the effluent from lemon grass met the WHO guideline value of $50 \mathrm{mg} / 1$ for wastewater. Removal efficiency for TDS was between $70 \%$ and $84 \%$ while that for the nutrients ranged between $8 \%$ and $81 \%$. Overall, lemon grass had the highest removal efficiency followed by elephant grass and then giant blue stem. Further research on a pilot scale where a continuous flow of greywater is established, and over a longer time period to determine the treatment performance over time is recommended.

\section{REFERENCES}

Agbozo, SK; Huibers, FP; Chenini, F Van Lier JB; Duran, A (2003). "Use of wastewater in irrigated agriculture, country studies from Bolivia, Ghana and Tunisia", Vol. 2: Ghana, Wageningen, WUR (W4F-wastwater).

Akinbile, CO; Yusoff, SM (2012). Int. J. of Phyto., 2012, 14, $201-211$.

American Public Health Association (APHA) (1998). Standard Methods for the Examination of Water and Wastewater. APHA, Washington, USA.17th Edition American Public Health Association, Washington DC. 1,268 pp.

Arceivala, SJ (1981). Wastewater Treatment and Disposal, Pollution Engineering and Technology/ 15, Marcel Dekker, Inc. NY.

Ambulkar, A; Nathanson, JA (2010). Encyclopaedia Britannica. Wastewater Treatment. Retrieved from

https://www.britannica.com/technology/wastewa ter-treatment

Asante, A. (2014). Phytoremediation Of Sewage Effluent With Some Selected Aquatic Plants From Anaerobically Digested Biogas Plant From The Valley View University Biogas Facility, Oyibi, Accra. pp 14

Berman, J (2009). WHO: Waterborne Disease is World's Leading Killer. Retrieved from https://www.voanews.com/archive/whowaterborne-disease-worlds-leading-killer

Bitton, G. (2005). Wastewater Microbiology. John Wiley \& Sons.

Börjesson, P; Berndes, G (2006). The prospects for willow plantations for wastewater treatment in Sweden. Biomass and Bioenergy. http://doi.org/10.1016/j.biombioe.2005.11.018

CISRO (2006). Literature review: Sources of critical contaminants in domestic wastewater. 55pp. (http//www.cisro.au). Accessed 4th January, 2011.

Clayton, WD; Harman, GRT; Williamson, H ; Vorontsova, M (2013). World checklist of Poaceae. Richmond, UK: Royal Botanic Gardens, Kew.

Crites, R; Tchobanoglous, G (1998): Small and Decentralized Wastewater Management Systems, McGraw Hill, New York.

Dannquah, JA; Roberts, CO; Appiah, M (2018). Elephant Grass (Pennisetum purpureum): A Potential Source of Biomass for Power Generation in Ghana. International Journal of Biodiversity Volume 2013, Article ID 874713, 7 pages http://dx.doi.org/10.1155/2013/874713

Dorgham, M (2014) Effects of Eutrophication. In: Ansari A., Gill S. (eds) Eutrophication: Causes, Consequences and Control. Springer, Dordrecht

Environmental Protection Agency (EPA), Ghana (2000), General Environmental Quality Standards (Ghana). Regulations 2000. pp8-13

Ghana Districts (2009). Kassena Nankana Municipality. Retrieved from (http://www.ghanadistricts.com/Home/District/1 54).

Guidi, NW; Jerbi, A; Lafleur, B; Fluet, R; Labrecque, M (2015). Willows for the treatment of municipal wastewater: Performance under different irrigation rates. Ecological Engineering.

http://doi.org/10.1016/j.ecoleng.2015.04.067

Gyampo, MA (2012). Wastewater Production, Treatment, and Use in Ghana. Department of Earth and Environmental Science, University for Development Studies, Navrongo, Ghana.

Hodgson, IOA Isaac, A (2000). Treatment of domestic sewage at Akuse (Ghana). Water S A Vol. 26, No. 3

Hodgson, IOA; Larmie, SA (1998). An evalution of the treatment efficiencies of the sewage treatment ponds at Akosombo, CSIR-WRI Technical Report 1998. Accra, Ghana.

Horváth, G (2012). Review of Subsurface Flow 
Treatment Wetland Feasibility in Finland,

Tampere University of applied Sciences, Tampere.

Kagya, AW (2011). Determination of Effluent Quality of two Wastewater Treatment Systems: An Activated Sludge Sewage Treatment Plant And Waste Stabilization Ponds at Juapong, KNUST MSc Thesis.

Kassena Nankana East Assembly (2015). Retrieved from https://www.Kassena-Nankana-East.pdf

Mason, CF (1996). Bilogy of Freshwater Pollution, Third Edition, Longman, England

Mesdaghinia, AR; Akhavan MP; Vaezi, F; Naddafi, K; Moosav, GH (2004). Waste Sludge Characteristics of a Wastewater Treatment Plant Compared with Environmental Standards, Iranian Public Health. 33. 1. 5-9

Metcalf and Eddy Inc. (1991). Wastewater Engineering: Treatment, Disposal, Reuse. 3rd Edition. McGraw-Hill, New York.

Mustafa, A (2013). International Journal of Environmental Science and Development, Vol. 4, No. 1, February 2013. Constructed Wetland for Wastewater Treatment and Reuse: A Case Study of Developing Country. Retrieved from https://www.researchgate.net/publication/271301 345 Constructed Wetland for Wastewater Tre atment and Reuse A Case Study of Developi ng_Country

Nkegbe, E; Emongor, V; Koorapetsi, I (2005). Assessment of Effluent Quality at Glen Wastewater Treatment Plant. Journal of Applied Sciences 5 (4): $647-650$.

Obuobie, EB; Keraita, G; Danso, P; Amoah, OO; Cofie, L; Raschid-Sally, D; Drechsel. P (2006) Irrigated Urban Vegetable Production in Ghana: Characteristics, Benefits and Risks. IWMI RUAF - CPWF

ORGANICA (2019). Wastewater Treatment Methods. Retrieved from https://www.organicawater.com/traditionalwastewater-treatment-methods-vs-organicasolutions/

OxyMem (2019). Four Major Operational Challenges Facing Wastewater Treatment Plants. Retrieved from https://www.oxymem.com/blog/4-majoroperational-challenges-facing-wastewater- $\underline{\text { treatment-plants }}$

Shah, J; Wahocho, N; Ghulam, L; Abdul, L; Ghulam, B; Hussain, T; Khalid ,AT; Wahocho, S; Lashari, A (2016). Role of Nitrogen for Plant Growth and Development: A review. Advances in Environmental Biology. 10. 209-218.

Sustainable Development Goals Report (2018). Progress of goal 6 in 2018. Retrieved from https://sustainabledevelopment.un.org/sdg6

UFZ (2011): Draft Project Plan - IWRM in Central Asia: Model Regional Mongolia (MoMo II), Ed.: Centre for Environmental Research.

UNICEF (2016). Assessment of Waste Water Treatment Plants In Ghana. Retrieved from https://www.unicef.org/ghana/assessment of wa ste_water_plant_report.pdf

United Nations Department of Economic and Social Affairs (UNDESA) (2015). Water for Life. Retrieved from https://www.un.org/waterforlifedecade/water_an d_sustainable_development.shtml

United Nations Development Program (UNDP) Ghana (2011). Kassena Nankana District Human Development Report 2011. Resource Endowment, Investment Opportunities and the Attainment Of the MDGs.

US EPA (2000). United States Environmental Protection Agency. Wastewater Technology Fact Sheet Free Water Surface Wetlands. EPA 832-F00-024. September 2000.

Vymazal, J; Kröpfelová, L (2008). Wastewater Treatment in Constructed Wetlands with Horizontal Sub-Surface Flow. Springer, Dordrecht.

World Health Organization (2019). Sanitation and Health (challenges). Retrieved from https://www.who.int/news-room/factsheets/detail/sanitation 